\title{
Silica Gel-Supported Cation Radical Catalyzed Diels-Alder Reaction
}

\author{
Myung-Jong Jin* and Sang-Eon Park \\ Department of Chemical Engineering and Chemistry, Inha University, Incheon 402-751, Korea. *E-mail: mjjin@inha.ac.kr \\ Received June 20, 2005
}

Key Words : Cation radical, Triphenylamine, Silica gel-supported, Diels-Alder reaction

The discovery of the cation-radical catalyzed Diels-Alder reaction opened a field of cation radical chemistry. ${ }^{1}$ The inefficiency of reactions involving neutral or electron-rich dienophiles imposes a major constraint on the Diels-Alder reaction. This reactivity constraint might be relieved by using cation radical which converts these dienophiles to their corresponding electron-deficient species. Bauld has reported that tris( $p$-bromophenyl) aminium hexachloroantimonate 1 was efficient for certain Diels-Alder reactions. ${ }^{2}$ The successful development of homogeneous catalysts has been often followed by attempts to attach them onto an insoluble polymeric support. ${ }^{3}$ The attachment of homogeneous catalysts to an insoluble support gives advantages over traditional solution phase chemistry. The immobilized catalysts can be separated from reaction mixture by simple filtration and then is easily regenerated for reuse. ${ }^{4}$ The method would be attractive from an economical viewpoint as well as a simplified work-up. Our interest in the area led us to prepare a silica gel-supported aminium cation radical.

Herein, we describe the synthesis of silica gel-supported triphenylamine cation radical $\mathbf{2}$ and its application in DielsAlder reaction.

As shown in Scheme 1, we prepared triphenylamine monomer $\mathbf{6}$ containing a reactive vinyl group which can be immobilized on a modified silica gel. The Friedel-Crafts reaction of triphenylamine with acetyl chloride provided $\mathbf{3}$ in $70 \%$ yield. Treatment of 3 with NBS gave 4 in $81 \%$ yield. Reduction of $\mathbf{4}$ with lithium aluminum hydride afforded $\mathbf{5}$ in $91 \%$ yield. Attempts to drive the next step to 6 by treatment of 5 with conventional dehydrating reagents such as $\mathrm{H}_{2} \mathrm{SO}_{4}$, $\mathrm{KHSO}_{4}, \mathrm{Al}_{2} \mathrm{O}_{3}$ and $\mathrm{POCl}_{3} /$ pyridine failed due to too low yield. In the case of $\mathrm{TsCl} / \mathrm{t}-\mathrm{BuOK}$, the formation of the<smiles>Brc1ccc(N(c2ccc(Br)cc2)c2ccc(Br)cc2)cc1</smiles><smiles>C=Cc1ccc(N(c2ccc(Br)cc2)c2ccc(Br)cc2)cc1</smiles><smiles>CC1CCCCC1</smiles><smiles>CC1([V])CCCCC1</smiles><smiles>CC[Si]1(CCCSCCCc2ccc(N(c3ccc(Br)cc3)c3ccc(Br)cc3)cc2)O[C@@H]2CO[C@@H](C)O[Si](OC)(O2)O1</smiles><smiles>c1ccc(N(c2ccccc2)c2ccccc2)cc1</smiles>

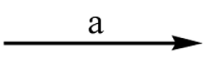<smiles>CC(O)c1ccc(N(c2ccc(Br)cc2)c2ccc(Br)cc2)cc1</smiles><smiles>CC(=O)c1ccc(N(c2ccc(Br)cc2)c2ccc(Br)cc2)cc1</smiles>

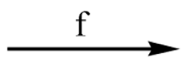<smiles>C#CC</smiles><smiles>CC(=O)c1ccc(N(c2ccccc2)c2ccccc2)cc1</smiles>

3

b 4<smiles>CCO[Si]12OC[C@H](CO[Si](CC)(CCCSCCCc3ccc(N(c4ccc(Br)cc4)c4ccc(Br)cc4)cc3)O1)O2</smiles>

Scheme 1. Reagents and conditions: a) $\mathrm{MeCOCl}, \mathrm{FeCl}_{3}, \mathrm{CH}_{2} \mathrm{Cl}_{2}$; b) NBS, DMF; c) $\mathrm{LiAlH}_{4}$, ether; d) TsOH, DMF; e) mercaptopropylated silica gel, $\mathrm{AlBN}, \mathrm{CH}_{3} \mathrm{Cl}$; f) $\mathrm{SbCl}_{5}, \mathrm{CH}_{2} \mathrm{Cl}_{2}$. 
monomer was accompanied by several by-products. Moreover, it could not be purified to a satisfactory level for further studies. We found an efficient dehydrating method using a catalytic amount of $\mathrm{TsOH}$ in DMF. Under this condition, the desired compound 6 was obtained in $70 \%$ yield. Reaction of triphenylamine monomer $\mathbf{6}$ with mercaptopropylated silica gel ${ }^{5}$ in the presence of AIBN in refluxing toluene gave silica gel-supported triphenylamine 7 $(0.29 \mathrm{mmol} / \mathrm{g})$. The supported triphenylamine 7 was converted to the silica gel-supported aminium hexachloroantimonate cation radical 2 upon reaction with antimony pentachloride $\left(\mathrm{SbCl}_{5}\right)$ in $\mathrm{CH}_{2} \mathrm{Cl}_{2}$. The cation radical is dark purple in color and appears to be stable in air for several days.<smiles>C1=CCCC=C1</smiles>
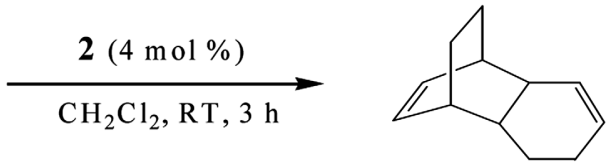

The Diels-Alder cyclodimerization of 1,3-cyclohexadiene requires $20 \mathrm{~h}$ at $200{ }^{\circ} \mathrm{C}$ to give $30 \%$ yield. ${ }^{5}$ When silica gelsupported aminium cation radical 2 was employed, the reaction was quite effective. The cyclodimerization of 1,3cyclohexadiene was achieved in the presence of the cation radical polymer in $71 \%$ yield in $3 \mathrm{~h}$ at room temperature. The supported cation radical $\mathbf{2}$ was easily regenerated and reused without significant loss of catalytic activity at second run.

The immobilized cation radical could relieve inefficiency of the Diels-Alder reaction involving electron-rich dienophile of 1,3-cyclohexadiene. Further work exploring the scope of the Diels-Alder reaction and the synthetic application of the supported cation radical is underway.

\section{Experimental Section}

1-[4-Bis(phenyl)aminophenyl]ethanone (3): To a cooled $\left(0{ }^{\circ} \mathrm{C}\right) \mathrm{CH}_{2} \mathrm{Cl}_{2}(30 \mathrm{~mL})$ solution containing triphenylamine ( $3 \mathrm{~g}, 12.2 \mathrm{mmol})$ and acetyl chloride $(0.96 \mathrm{~g}, 12.2 \mathrm{mmol})$ was added $\mathrm{FeCl}_{3}(1.4 \mathrm{~g}, 8.5 \mathrm{mmol})$. The mixture was stirred at $0{ }^{\circ} \mathrm{C}$ for an additional $1 \mathrm{~h}$. The cooling bath was removed and the mixture was allowed to reflux for $4 \mathrm{~h}$. After work up, the residue was chromatographed on silica gel to give product 3 (2.3 g, 70\%): ${ }^{1} \mathrm{H}$ NMR $\left(\mathrm{CDCl}_{3}, 250 \mathrm{MHz}\right): \delta 7.79$ $(\mathrm{d}, J=9.0 \mathrm{~Hz}, 2 \mathrm{H}), 7.31(\mathrm{~d}, J=5.9 \mathrm{~Hz}, 4 \mathrm{H}), 7.14(\mathrm{~m}, 6 \mathrm{H})$, $6.98(\mathrm{~d}, J=9.0 \mathrm{~Hz}, 2 \mathrm{H}), 2.54(\mathrm{~s}, 3 \mathrm{H}) ;{ }^{13} \mathrm{C} \mathrm{NMR}\left(\mathrm{CDCl}_{3}\right): \delta$ 96.5, 152.2, 146.5, 129.9, 129.8, 126.0, 124.7, 119.6, 116.3, 26.3.

1-[4-Bis(4-bromophenyl)aminophenyl]ethanone (4): A DMF $(15 \mathrm{~mL})$ solution of $3(1.5 \mathrm{~g}, 5.0 \mathrm{mmol})$ was treated with NBS (1.9 g, $10.4 \mathrm{mmol})$. The mixture was stirred at room temperature for $1 \mathrm{~h}$ and then heated to $50{ }^{\circ} \mathrm{C}$ for an additional $10 \mathrm{~h}$. After work up, After work up, the residue was chromatographed on silica gel to give product 4 (1.9 g, $81 \%)$ as a yellow solid: ${ }^{1} \mathrm{H} \mathrm{NMR}\left(\mathrm{CDCl}_{3}, 250 \mathrm{MHz}\right): \delta 8.03$ (d, $J=8.5 \mathrm{~Hz}, 2 \mathrm{H}), 7.63(\mathrm{~d}, J=8.6 \mathrm{~Hz}, 4 \mathrm{H}), 7.20(\mathrm{~m}, 6 \mathrm{H})$, $2.75(\mathrm{~s}, 3 \mathrm{H}) ;{ }^{13} \mathrm{C} \mathrm{NMR}\left(\mathrm{CDCl}_{3}\right): \delta 186.5,151.3,145.3$, $132.8,130.0,129.9,129.7,120.7,117.5,28.3$.

1-[4-Bis(4-bromophenyl)aminophenyl]ethanol (5): To a solution of lithium aluminum hydride $(60 \mathrm{mg}, 1.6 \mathrm{mmol})$ in anhydrous diethyl ether $(4 \mathrm{~mL})$ at $0{ }^{\circ} \mathrm{C}$ was slowly added compound 4 (1.0 g, $2.2 \mathrm{mmol})$ dissolved in diethyl ether (8 $\mathrm{mL}$ ). The mixture was heated to $40{ }^{\circ} \mathrm{C}$ and allowed to react for $6 \mathrm{~h}$. After work up, purification was achieved by flash chromatography to give product $5(0.92 \mathrm{~g}, 91 \%)$ as a light yellow solid: ${ }^{1} \mathrm{H} \mathrm{NMR}\left(\mathrm{CDCl}_{3}, 250 \mathrm{MHz}\right): \delta 7.34$ (d, $J=8.9$ $\mathrm{Hz}, 4 \mathrm{H}), 7.28$ (d, $J=8.1 \mathrm{~Hz}, 2 \mathrm{H}), 6.99(\mathrm{~m}, 6 \mathrm{H}), 4.41$ (m, 1H), 1.76 (br s, 1H), 1.51 (d, $J=6.4 \mathrm{~Hz}, 3 \mathrm{H}) ;{ }^{13} \mathrm{C} \mathrm{NMR}$ $\left(\mathrm{CDCl}_{3}\right): \delta 146.4,141.0,132.3,132.1,126.7,125.3,124.6$, 115.4, 69.9, 25.0. Anal. Calcd: C, 53.66; H, 3.89\%. Found: C, 53.73; H, 3.83\%.

1-[4-Bis(4-bromophenyl)aminophenyl]ethene (6): A DMF (6 mL) solution containing $5(0.8 \mathrm{~g}, 1.8 \mathrm{mmol})$ was treated with a catalytic amount of $p$-toluenesulfonic acid (20 $\mathrm{mg}, 0.1 \mathrm{mmol}$ ). After $10 \mathrm{~min}$ of reaction, the mixture was allowed to reflux over a period of $50 \mathrm{~min}$. After work up, the residue was purified by column chromatography to provide product 6 as a light yellow power $(0.51 \mathrm{~g}, 70 \%$ yield $):{ }^{1} \mathrm{H}$ NMR $\left(\mathrm{CDCl}_{3}, 250 \mathrm{MHz}\right): \delta 7.35(\mathrm{~m}, 6 \mathrm{H}), 6.98(\mathrm{~m}, 6 \mathrm{H})$, $6.68(\mathrm{dd}, J=17,11 \mathrm{~Hz}, 1 \mathrm{H}), 5.69(\mathrm{~d}, J=17 \mathrm{~Hz}, 1 \mathrm{H}), 5.22$ $(\mathrm{d}, J=11 \mathrm{~Hz}, 1 \mathrm{H}) ;{ }^{13} \mathrm{C} \mathrm{NMR}\left(\mathrm{CDCl}_{3}\right): \delta 146.4,146.3,136.0$, 132.4, 132.2, 127.3, 125.5, 124.2, 115.7. 112.9. Anal. Calcd: C, 55.97; H, 3.50\%. Found: C, 55.87; H, 3.53\%.

Immobilization of 6 on silica gel: Mercaptopropylated silica gel $(400 \mathrm{mg}, 1.1 \mathrm{mmol} / \mathrm{g})$ was suspended in toluene and refluxed with monomer $6(100 \mathrm{mg}, 0.23 \mathrm{mmol})$ and AIBN (14 mg) as radical initiator for 48 hours. The powder was collected by filtration and washed with methanol and methylene chloride. After drying in vacuo at $65{ }^{\circ} \mathrm{C}$, silica gel-supported triphenylamine $7(458 \mathrm{mg})$ was obtained. Weight gain showed that loading ratio of $\mathbf{6}$ was 0.29 $\mathrm{mmol} / \mathrm{g}$.

Silica gel-supported triphenylaminium hexachloroantimonate (2): Supported triphenylamine 7 (400 $\mathrm{mg})$ was suspended in $\mathrm{CH}_{2} \mathrm{Cl}_{2}(3.5 \mathrm{~mL})$ and $\mathrm{SbCl}_{5}(0.15 \mathrm{~mL})$ was slowly added at $-20{ }^{\circ} \mathrm{C}$. The mixture immediately turned deep blue. After stirring for $20 \mathrm{~min}$, the polymer was collected on a glass frit, washed with $\mathrm{CH}_{2} \mathrm{Cl}_{2}$, and then dried under reduced pressure at $75{ }^{\circ} \mathrm{C}$ to yield 2 (432 mg, 0.26 $\mathrm{mmol} / \mathrm{g}$ ).

Diels-Alder reaction of 1,3-cyclohexadiene in the presence of supported cation radical 2: $\mathrm{To}_{\text {a }} \mathrm{CH}_{2} \mathrm{Cl}_{2}(1.0$ $\mathrm{mL})$ solution of 1,3-cyclohexadiene $(100 \mathrm{mg}, 1.25 \mathrm{mmol})$ was added supported cation radical 2 (185 mg). The mixture was allowed to stir at room temperature for $3 \mathrm{~h}$. The immobilized catalyst $\mathbf{2}$ was separated by centrifugation. Solvent and the remaining 1,3-cyclohexadiene was removed under reduced pressure. The residue was purified by flash chromatography to give cyclohexadiene dimer in $71 \%$ yield.

Acknowledgment. We appreciate Nano Center for Fine Chemicals Fusion Technology for financial support. 


\section{References}

1. (a) Gassman, P. G.; Singleton, D. A. J. Am. Chem. Soc. 1984, 106, 7993. (b) Bauld, N. L. Tetrahedron 1989, 45, 5307. (c) Bauld, N. L.; Harirchian, B. J. Am. Chem. Soc. 1989, 111, 1826.

2. Bauld, N. L.; Bellville, D. J.; Wirth, D. D. J. Am. Chem. Soc. 1981, 103, 718

3. (a) Gladysz, J. A. Chem. Rev. 2002, 102, 3512. (b) Wight, A. P.; Davis, M. E. Chem. Rev. 2002, 102, 3589 .
4. (a) Hodge, P.; Sherrington, D. C. Polymer-Supported Reactions in Organic Synthesis; Wiley: New York, 1980. (b) Akelah, A.; Sherrington, D. C. Chem. Rev. 1981, 81, 557. (c) Baxendale, I. R.; Ley, S. V.; Piutti, C. Angew. Chem. Int. Ed. Engl. 2002, 41, 2194.

5. (a) Song, C. E.; Yang, J. W.; Ha, H, J. Tetrahedron: Asymmetry 1997, 8, 341.

6. Valentine, D.; Turro, N. J.; Hammond, G. S. J. Am. Chem. Soc. 1964, 86, 5202 . 